\title{
O estojo e o adereço Transformações da domus aurea burguesa e romance peninsular contemporâneo
}

Pedro Serra

Para a Vilma Arêas,

com amizade e a presença do tempo paulista

Ecce imago: plano em contraluz de Felicidad Blanc no documentário El desencanto (1976). Mulher do poeta Leopoldo Panero, mãe de Juan Luís, Leopoldo María e Michi: sozinha, sentada num sofá, recordando - na casa vazia de Castrillo de las Piedras (Astorga) - os momentos fulcrais do enamoramento e casamento com Leopoldo. O registo fotográfico do filme de Jaime Chávarri ${ }^{1}$, diríamos, sublinha ainda mais o efeito de contraluz; um excesso de luz - uma revelação sobre-exposta, 'queimada' - vai como que absorvendo Felicidad Blanc. Ao mesmo tempo, eis-nos perante a figura de Felicidad Blanc instalada numa aporia enunciativa. Por um lado, a demanda do íntimo, tanto pessoal como familiar, demanda crepuscular pautada pela Sonata para piano no 20 en Lá Maior, D 959 de Schubert. Este íntimo demandado é a sobrevivência do oitocentismo romanesco que a identifica. Felicidad Blanc imagina-se heroína de um romance do século XIX. Um rasgo que, como mais adiante explicito, a assimila a uma qualquer personagem de ficção, e.g. Maria dos Prazeres de Uma Abelha na Chuva (1953) de Carlos de Oliveira.

Em El desencanto a demanda de intimidade é objectivada no tropo - também oitocentista - do 'interior' habitado. A questão deste documentário - como de resto, a questão e o tema do breve corpus ficcional que elejo como objecto de análise neste ensaio - é oitocentista na medida em que é na narrativa burguesa heróica de oitocentos que se coagula o que chamaria 'problema da habitação'. Habitar o íntimo convoca a tropologia sedimentada pela afirmação histórica - mitificação e naturalização históricas - da burguesia. Contudo, esta habitação do íntimo e do interior ocorre num momento - o momento especular e auto-referencial do documentário - em que esta epopeia e esta etopeia burguesas claudicam, conhecem o seu desenlace.

Sigo, aqui, muito concretamente, um insight benjaminiano que encontramos no Livro das Passagens. Convoco uma nota mínima, um facto mínimo, mas que como facto é toda uma teoria. Diz-nos Benjamin: Desenlace do capitulo sobre o interior: aparição do adereço no cinema. ${ }^{2}$ É essa transmutação degradada que temos em El desencanto: o 'interior' da casa de Castrillo de las Piedras (Astorga) impondo-se gradualmente como adereço. O objecto doméstico vai cedendo o papel de vestigium da subjectividade em detrimento da sua funcionalização como atrez̨o cenográfico. O problema da habitação, tal como é performativizado por Felicidad Blanc, assenta na progressiva distensão da dialéctica entre a conservação do intimo (pessoal, familiar, comunitário) e a sua degradação. Progres- 
sivamente se deflecte, para seguir os termos benjaminianos, a tensão entre o estojo e o adereço:

A maior dificuldade na ponderação do facto de habitar reside, por um lado, em termos de reconhecer nele o antiquíssimo - talvez o eterno: a reprodução da estância do homem no seio materno; por outro lado, à margem deste motivo pré-histórico, há que compreendê-lo na sua forma mais extrema como estado existencial do século XIX. A forma prototípica de toda a habitação não é estar numa casa, mas sim num estojo. Este estojo exibe as marcas do seu inquilino. No extremo, a vivenda converte-se em estojo. O século XIX estava mais ansioso de habitar do que nenhum outro". 3

Eis, pois, os termos do problema da habitação: a vivenda como estojo, como lugar em que habitam as marcas do inquilino; a vivenda como adereç, como lugar em que sobrevém a abjecção do inquilino. El desencanto lança-nos de borco neste processo de transformação da domus aurea burguesa. O documentário colige imagens que são, sem dúvida, passagens obrigatórias para equacionar este problema da babitação na cultura peninsular contemporânea. Sendo que esta contemporaneidade peninsular, do meu ponto de vista, imperativamente responde à transição das Ditaduras para as Democracias.

A luz queimada que envolve Felicidad - mas também Juan Luis, Leopoldo María ou Michi - é, digamos, o significante proposto pelo documentário cinematográfico de um halo ameaçador que envolve e devora vorazmente o núcleo familiar conspurcado. Expulsão do éden, ninho progressivamente corroído, que sugere, aliás, enterramento in vivo, esterilidade uterina ou crime doméstico. Aquele mesmo halo que temos a envolver a Gândara de Carlos de Oliveira, em uma Abelha na Chuva, halo que progressivamente se foi objectivando até ao seu último romance, Finisterra (1978). No centro da óikos, no âmago da domus aurea burguesa, a irradiação do crime, um crime que fascina os indivíduos, que os lança no entre-lugar do privado vs. público, do sonho (pesadelo) vs. vigília, do sujeito vs. estado, da confissão vs. manifesto.

Augusto Abelaira, em A Cidade das Flores (1959), conjurara também este problema da habitação na alusão a um dos seus emblemas mais potentes: o da família originária. A cena, agora, é a da contemplação de um quadro, concretamente da Expulsão de Adão e Eva do Paraíso, quadro de Masaccio que se encontra na Capela Brancacci da Igreja de Santa Maria del Carmine, em Florença. O contemplador é a personagem Giovani Fazio, que visita a igreja florentina. Lemos na obra, pois, seguindo o ponto de vista de Giovani Fazio, enfatizando desde já a obstrução da vista do expulsado Adão e da expulsada Eva:

E o Anjo terrível expulsa Adão e Eva do Paraíso. Mas porque cobre Adão o rosto com as mãos? Saberá ele o que é a Terra, para fechar assim os olhos? Por que essa certeza antecipada de que a Terra é um mal? Eva grita como se conhecesse toda a miséria, todo o sofrimento que a espera. Mas não sabe, não pode saber. Têm medo daquilo que ignoram: choram, embora desconheçam; fecham os olhos para não ver o que ainda não sabem se é bom, se mau. ${ }^{4}$

Temos também aqui, como vemos, outra modulação de um desencanto, aquele que é devolvido pela certeza antecipada de um futuro suspenso. Contudo, há ainda uma abertura, que é de resto a que tensa um romance como o de Abelaira onde revebera uma cidade das 
flores. Abertura significa, neste sentido, que o futuro oscila ainda entre uma certeza e um desconhecimento.

Tanto no halo lumínico envolvendo Felicidad Blanc, como na invidência voluntária do casal original do quadro de Masaccio, temos dois momentos narrativos em que se obstrui a possibilidade de objectivar uma visio de reconciliação da sociedade. Há sem dúvida diferenças entre as duas imagens. Todavia, convergem ambas no colapso de uma retórica da temporalidade em que a visão do social reconciliado se apoia numa metafísica secularizada da História. O que, enfim, está em causa tanto na vidência obturada de Adão e Eva e no drama psicossocial da família Panero é a possibilidade de a arte mediar a prognose de um tempo que, assolando o presente, não permita ao presente ser o melhor dos mundos possíveis.

Pensadas em função do cronótopo ibérico a que me reporto - o da passagem de um tempo ditatorial a um tempo democrático -, ambas as imagens são-no de um futuro suspenso, ficções que não visam produzir alternativas, provocar decisões. Ficções também elas obstruídas que, seguindo uma conhecida formulação adorniana, não propõem a representação de verdades políticas: Quanto menos, porém, as obras têm que anunciar algo em que elas não podem acreditar completamente, tanto mais coerentes se tornam elas próprias. Um bom exemplo encontramo-lo ainda em Quatro Paredes Nuas, do já citado Augusto Abelaira, num lugar do conjunto ficcional onde ecoa a Guerra Civil Espanhola: - A vitória republicana em Teruel marcou uma volta decisiva na evolução da guerra. Os nacionalistas estão perdidos, não há auxílio estrangeiro que lhes valha. ${ }^{6}$ A vitória, recordemo-lo, seria determinada por algo como a marcha implacável da história, uma História legiferada por coisas como as contradições do capitalismo ou a luta de classes ${ }^{7}$. Teruel tomada, Madrid inconquistável... Contrafactuais que não obviam que, todavia, como lemos no mesmo Quatro Paredes Nuas, de 1972, essa marcha implacável da história é uma fantasia ${ }^{8}$.

Enfim, algo irredutível nas Ditaduras peninsulares pervive para além do advento das respectivas Democracias, cuja instauração é subsumida ainda por um universo Sem tecto, entre ruínas. Neste romance de 1978, Abelaira ajustará os tempos português e espanhol, pela boca das personagens Ernesto e João Gilberto: O que vemos em Espanha pode vir a repetir-se em Portugal. - Já lá chegou a democracia, o Franco acabou? ${ }^{9}$ Franco não acabara, como tão-pouco a figura paterna do poeta Leopoldo Panero no documentário El desencanto, figura cuja presença post-mortem, cuja presença in absentia, trunca a possibilidade de um tempo adventício. Simbólica pregnante, esta, e que responde claramente a ditaduras demasiado longas, suficientemente longas para determinar a exautoração das pulsões prognósticas. Democracias que, enfim, sobrevêm como algo súbito e simultaneamente tardio.

Retomemos a imagem inicial do plano em contraluz de Felicidad Blanc. O efeito é o de des-realizar a silhueta, que assim adquire contornos fantasmáticos. Persona na mais descarnada solidão - baixo-contínuo cuja veemência é ensurdecida pela Sonata para piano $n^{\circ} 20$ en Lá Maior, D 959 de Schubert -, persona que constrói e rememora um mundo progressivamente perdido. É ela própria, ao cifrar-se como persona(gem), que se vai perdendo. Como produção de uma auto-consciência tem como corolário o enfrentamento à mais absoluta anacronização de Felicidad, que acabará por reconhecer não ter presente, 
e, mais ainda, nunca o ter tido: O meu século foi o século XIX, na minha infância sentia ainda o seu esplendor. ${ }^{10} \mathrm{O}$ momento de verdade da personagem, enfim, acontece nesta auto-assunção como imagem fantasmática. Felicidad é uma sombra geradora de sombras. ${ }^{11} \mathrm{O}$ halo lumínico expõe e absorve Felicidad e os filhos, é o limite do espaço tumular, do encoframento na casa de Castrillo de las Piedras. A memória é também esse cofre.

Esta imagem, insisto, serve de passagem para reler a cultura peninsular das etapas político-sociais de transição da ditadura para a democracia em Espanha e em Portugal em função do problema da intimidade, do homo interior que palpita no documentário de Chávarri. Numa re-descrição possível, interessa-me destacar o que na ampla fenomenologia da cultura romanesca transicional se representa como processo à família, para utilizar a expressão de uma notável ensaísta catalã, Maria José Ragué Arias. Ragué também autora de livros de referência para conhecer a cultura transicional peninsular como California Trip e Los movimientos pop - organizou um volume intitulado Proceso a la familia española (1979), reunindo nele entrevistas e depoimentos de políticos centristas e da esquerda ideológico-partidária, membros destacados do movimento e organizações feministas, intelectuais de vários âmbitos (escritores, sociólogos, juristas, médicos, psicólogos figuras do mundo do espectáculo). A família é, enfim, pensada no quadro de um pensamento da utopia, isto é, de um pensamento revolucionário:

Como alternativa utópica cabe pensar numa sociedade sem classes formada por indivíduos livres, autónomos e solidários entre si, que se relacionem livremente e na qual o território da afectividade pertencesse à intimidade e não estivesse institucionalizado nem condicionado por interesses materiais. Neste caso, a família actual poderia ser uma alternativa mais livremente escolhida e não institucionalizada. ${ }^{12}$

Nesses idos de 1979, o momento é vivido como tentativa de abertura utópica de uma instituição que, pelo contrário, e como no-lo refractam diferentes romances, era antes a cifra da alienação dos indivíduos. Vejamos alguns exemplos. Como El desencanto, Uma Abelha na Chuva de Carlos de Oliveira diz-nos de um mundo - a Gândara - que vai progressivamente perdendo latência, sem todavia se extinguir por completo. Por um lado, é um mundo todo, auto-contido, auto-suficiente. Mas, por outro, é um universo progressivamente crepuscular. É uma escala de intimos, alguns deles já plenamente calcificados, alienados, objectivados. Tem vindo a ser destacado, justamente, o carácter fantasmático do mundo nomeado Gândara, e Uma Abelha na Chuva é bem o exemplo do assédio de diferentes mortos ao crânio dos vivos. Gostaria, neste sentido, de propor a figura de um mundo que, com ser morto, é sobretudo um mundo enterrado vivo, um mundo de enterrados vivos. É sob esta luz, sob a luminosidade deste topos de longa tradição literária, que leio um conjunto de imagens que percorrem a obra, e que reduziria a essa ideia de um encoframento in vivo. Lemos logo no primeiro capítulo: Havia sobre a vila, ao redor de todo o horizonte, um halo de lur branca que parecia rebordo duma grande concha escurecendo gradualmente para o centro até se condensar num côncavo alto e tempestuoso. ${ }^{13}$ Um universo que se dobra sobre si próprio, que se enconcha. A mesma sugestão de fechamento podemos encontrá-la no seguinte passo, emblema do casal do Montouro: Quantas vezes o vira meter o ombro à muratha que ela erguia entre os dois, como quem bate às cegas numa porta recôndita que não sabe onde é 
nem para onde dá e ali fica toda a noite, aos umbrais, gelado e miserável ${ }^{14}$. Enterramento, asfixia a dois, mas também no círculo mais reduzido do ego.

A crítica ao casamento burguês, cuja dramatização é encarnada pela conjugalidade alienada de Álvaro Silvestre e Maria dos Prazeres, passa pela necessidade de o interpretar como Utopia que falha. Com ser bela - o casal do Montouro é colmeia, uma figuração do belo - a Utopia é vítima de si própria: O ponto fraco das utopias, porque têm um, consiste na sua qualidade de negócios perdidos à priori; belos mas (redundantemente) utópicos ${ }^{15}$. Carlos de Oliveira remete, neste sentido, para a problemática conjugal em Augusto Abelaira, mas o que medita fere retroactivamente a encenação de Uma Abelha na Chuva:

A crítica de Abelaira ao casamento burguês irradia de uma ideia semelhante, pelo menos em parte. O casamento, donde sai a juventude a reencontrar (os filhos), não constitui uma venda da alma (da liberdade de amar) ao único Diabo que conhecemos, as instituições, a moral corrente ${ }^{16}$

Identificamos aqui a seguinte aporética: o casamento é investido de uma carga utópica (juventude/filhos), sendo igualmente instituição moral que determina a redundância desse utopismo. O que a Carlos de Oliveira interessa é a retórica da temporalidade associada ao casamento burguês. Nele um passado por cumprir - a juventude, ou o irrealizado nesse momento de origem - é lançado como futuro que clama uma realização impossível: um regresso impossível. Assim, é essa juventude a reencontrar que sustenta a instituição moral, colectivização desse anelo do indivíduo. A moral corrente é venda da alma enquanto esquecimento (individual e colectivo) desse inalienável diferimento.

Em sede adorniana, ainda que por via diferente, identifica-se também uma tensão aporética que envilece a instituição, artimanha para a auto-conservação, que leio como um equivalente da juventude a reencontrar:

Um casamento aceitável seria apenas aquele em que ambos tivessem a sua própria vida independente, sem nada daquela fusão produto da comunidade de interesses determinada por factores económicos, mas que assumissem livremente uma responsabilidade recíproca. $\mathrm{O}$ casamento como comunidade de interesses supõe irrecusavelmente a degradação dos interessados, e o pérfido desta organização do mundo é que ninguém, ainda que sabendo porquê, pode escapar de tal degradação ${ }^{17}$.

Neste sentido, o amor não redime, como de resto o sabia bem Álvaro Silvestre: mas eu amo-a apesar de tudo, amo-a tanto que não posso vê-la no inferno, sufocada, perdida ${ }^{18}$. Não adianta descontar o que neste enunciado possa ser enunciação do brandy - ou não fosse o amor assimilável a um estado de embriaguez; ou a embriaguez fonte de momentos de verdade da personagem. O casamento por interesse, o casamento concertado, de que é exemplo o casal do Montouro - aliando aristocracia provinciana decadente e burguesia rural -, não é incompatível com a ideologia do amor.

No romance Tiempo de silencio de Luis Martín-Santos, por seu turno, o valor projectivo num tempo de silêncio franquista - na obra articulado como desgarramento entre a continuidade de uma sociedade miserável e a emergência do desenvolvimentismo sessentista - proviria de um desenlace matrimonial também "arranjado", mythos certa- 
mente melodramático, projectividade truncada pelo assassinato de Dora, a noiva destinada a Pedro. Ao mesmo tempo, e em contraponto com as disfunções morais do universo social pequeno-burguês e burguês urbano, temos o núcleo familiar patriarcal extramuros da família de Muecas. Um núcleo também ele extra-moral, que oculta um crime, o crime do incesto Muecas/Florita.

No quadro do casamento arranjado o amor pode conservar o carácter de imponderado ou acaso, à volta do qual de resto orbita o casamento em Bolor, de Augusto Abelaira ${ }^{19}$. A paixão do amor pressupõe a sua plena autonomia, o que significa o poder unir um homem a uma mulher ou outra ${ }^{20}$, ou uma mulher a um homem ou outro. O amorsentimento como codificação da intimidade não é, neste sentido, sem concessões ao social - por outras palavras não é um sentimento em si mesmo, mas antes um código de comunicaçã ${ }^{21}$ - e, enquanto tal, código comportamental simulável como formula Niklas Luhman:

Estas condições ajudam a compreender o facto de a codificação da intimidade (de base sexual) ter sobretudo início à margem da ordem estabelecida e que se tenha de remir esta possibilidade através de 'concessões' feitas à semântica - sobretudo através do reconhecimento da insensatez, da loucura, da instabilidade. Só após a habituação a um tal programa se poderia iniciar com seriedade a construção de uma reciprocidade social visar a formação sistémica assim estabilizada - cujo sucesso é discutido até aos dias de hoje $\mathrm{e}^{22}$.

O preço que paga esta autonomia de código, pela qual o amor se justifica a si próprio apoiado numa semântica transmitida pela tradiçãa $0^{23}$, é o de se saber como se tivesse origem no nada ${ }^{24}$ e o de tornar difícil a reprodução da intimidade:

Os casamentos são contraídos no céu, no carro verifica-se a separação, pois aquele que está ao
volante comporta-se de acordo com a situação e conduz - pensa ele - tão bem quanto sabe;
mas aquele que vai ao lado e o observa sente-se objecto do modo como o outro conduz,
remetendo esse mesmo modo de conduzir para as características do condutor. Só pode agir
de uma maneira, precisamente através do comentário e da crítica; e é pouco provável que ao
fazê-lo obtenha o assentimento do condutor ${ }^{25}$.

Álvaro Silvestre e Maria dos Prazeres também perfazem esta cena de separação, não no carro mas na charrete, não conduzindo mas sendo conduzidos. O que fica imediatamente claro é que a falta de assentimento mútuo nos devolve a ausência dessa intimidade, consumação dessa sua reprodução inverosímil. A crise, e a crítica, do casamento burguês implica, pois, a crítica da individuação burguesa. ${ }^{26}$ Desse ponto de vista, o encoframento é a cifra de uma solidão ensimesmada. O homo interior não abdica de uma pessoal promesse de bonheur num universo que, como diagnosticou Freud, lhe nega a todo o momento esse horizonte redentor. O nó cego é este: de um lado, a impossibilidade de retorno da inocência; do outro, a necessidade de uma transparência - uma confissão absoluta que se objectivasse como num diário - que tiraniza. As personagens aferram-se aos sonhos (intransitivos) como expediente de conservação (ilusória) da intimidade: o desforço vai exaurindo a energeia.

Por último, aludo a La fea burguesía, de Miguel Espinosa, romance que perfaz a summa teologiae desta exautoração energética, multiplicando os avatares conjugais. "Suma 
teológica", insisto, do tardofranquismo e, na leitura de Teresa Vilarós, anunciação do pós-franquismo dos anos 80. A família burguesa - que aqui refere fundamentalmente a classe burocrática que legitima e é legitimada pelo aparelho de estado fascista -, ao contrário dos exempla até agora considerados, não assenta numa conjugalidade enredada em dramas de consciência que vão exautorando o homo interior. O cenário do desencanto, a compulsão a produzir mais e mais solidão, desapareceu por completo. Dito de outro modo, o mundo perdeu toda e qualquer latência.

Neste sentido, não estou totalmente de acordo com parte da descrição da responsabilidade da já mencionada Teresa Vilarós:

O romance [La fea burguesía] multiplica-se em fragmentos, em quadros 'vivos' que nos mostram, quase como uma 'câmara indiscreta', diferentes momentos, posições e atitudes daqueles que pertencem à burguesia. Estes passam diante dos nossos olhos descritos pelos seus gestos e atitudes rituais, os seus comportamentos sociais e os seus hábitos. ${ }^{27}$

Não partilho, muito concretamente, a figura da câmara indiscreta. Sim diria que este é um tropo que valeria, por exemplo, para o documentário de Chávarri. Todavia, no romance de Espinosa não há qualquer intimo, qualquer interior, que nos devolvesse o encoframento da casuística ficcional até aqui tratada, toda ela tensada pela hipóstase do homo interior e da utopia. Algo novo é enfrentado por La fea burguesía. Para dizer essa diferença, que tem uma determinante contrapartida na poética do romance, Miguel Espinosa articulou a noção - densa noção - de utopia negativa. Um único atributo destes burgueses feios torna notória a diferença: a burguesia vive num presente absoluto, isto é, realizou-se por completo, para ela o tempo não está fora dos gonzos. É essa plena realização burguesa que se nos representa em La fea burguesía.

Diria, então, que estes romances propõem diferentes expulsões de Evas e Adões do paraíso... Percorre este mínimo corpus romanesco peninsular o centramento das respectivas fábulas num espaço intimo reificado por valores burgueses e pequeno-burgueses. $\mathrm{Na}$ domus aurea burguesa imiscui-se um bolor. Confrontado com a ausência de um fundamento metafísico para a sua relação, o casal formado por Maria dos Remédios e Humberto (Bolor) representa uma intimidade auto-ilusória que tem na distorção e progressiva evanescência da voz narrativa a sua contrapartida. Também Dora/Pedro (Tiempo de silencio), Maria dos Prazeres/Álvaro Silvestre (Uma Abelha na Chuva), Cecilia/ Castillejo, Pilar/Clavero, Cayetana/Krensler ou Purificación/Paracel (La fea burguesía), nomeiam esta como que 'estética de desaparição' da domus aurea burguesa.

Complexa matéria também a exposta pelo romance familiar dos Panero. Vejamos. Se lermos de perto uma interpretação do caso como a que é levada a cabo por Teresa Vilarós ${ }^{28}$, damos conta da centralidade que nela ocupa a figura do poeta Leopoldo Panero, o pater familias. Todavia, na leitura que proponho - leitura com refluxos para os romances mencionados - gostaria de centrar a atenção em Felicidad Blanc. Ou melhor, suplementando o elenco de casais atrás discriminado, em Felicidad/Leopoldo. Mais ainda, farei a entrada no círculo do trauma familiar através da mater familias.

Para tanto, recorro ao volume Espejo de sombras, publicado em 1977, relato autobiográfico de Felicidad Blanc, onde se diz do fim de uma propriedade: a casa de família 
de Felicidad, a casa paterna. Memória de ausências, nascida da falta, nascida de um vazio que, contudo, deixa uma marca indelével:

A casa já não existe, mas volto a vê-la na minha memória na parede deteriorada da escadaria, ou naquela aldraba estragada que não fecha, ou naquela roseira doente à esquerda que nunca cresceu como as outras. Pormenores que aparentavam ser nada e que, contudo, com o passar do tempo, regressam com a humildade das coisas pequenas em que um dia te fixaste, objectos que olhaste com o desdém com que observas o que é susceptível de ser arranjado. E agora são elas que te atraem, que transportas contigo ao subir, na lembrança, aquelas escadas, ou abrir aquela porta que já nada abrirá. ${ }^{29}$

Felicidad pretende, assim, resolver o problema económico da família depois da morte do poeta Leopoldo Panero.

A venda da casa paterna remonta a 1964, dois anos depois da morte do marido. Salva, nessa ocasião, os móveis de família, que traslada para Castrillo de las Piedras, a casa em Astorga onde viveu com Leopoldo e onde nasceram Juan Luís, Leopoldo María e Michi. Tão-pouco essa propriedade acabará por pertencer-lhe, é herança dos filhos e dos irmãos do marido. Também no documentário se faz alusão à venda dos bens patrimoniais, neste caso o recheio da casa de Castrillo, em Astorga. Em primeiro lugar, venderam-se os livros, vendeu-se a biblioteca do poeta falangista Leopoldo Panero. De tal modo que, quando revisitado Castrillo de las Piedras, a casa é já uma casa esvaziada, destripada. São, aliás, vários os travellings por esse espaço doméstico ausente, que a câmara de Chávarri vai sublinhando na sua espectralidade e tumularidade, com uma veemência melancólica acompanhada pela supra mencionada Sonata para piano $n^{0} 20$ en Lá Maior, D 959 de Schubert. O operador narrativo do documentário, sublinho este facto, é a memória de Felicidad Blanc. Espejo de sombras concluirá com a referência às filmagens de El desencanto: Depois veio a filmagem em Castrillo, após vários anos de ausência. As casas destruidas, as vidraças partidas, o frio insuportável e as minhas lágrimas que interrompem as filmagens. ${ }^{30}$ Como testemunho e documento, o relato de Felicidad Blanc visa, pois, através da escrita e do livro, responder ao documentário de Jaime Chávarri, El desencanto.

Como se o documentário pretendesse encerrar a vida de Felicidad e da família Panero, como se se jogasse nele a verdade daquele romance familiar. E, contudo, há algo de irredutível nesse romance, algo que o documentário não consegue reduzir a imagens ou palavras, algo que tão-pouco é abarcado pelo livro autobiográfico Espejo de sombras. Documentário e livro pretendem dar voz à sombra especular que Felicidad Blanc foi durante toda a vida - na infância, na juventude, como mulher do poeta Leopoldo Panero -, encarnar-lhe a voz, incorporar-lhe a voz. Todavia, algo se perde nessas narrativizações. É a própria Felicidad Blanc quem no-lo diz, comentando o tempo que veio depois de El desencanto: [Senti] que por fim me separei do que ainda me prendia a uma sociedade que não me interessava. O ser eu, eu mesma. ${ }^{31}$ Assim, na primeira projecção privada do filme, sobrevém a sensação de não acabar de encontrar-me, a sensação de não ser completamente eu. Aquela mulher irritava-me. E na estreia, presa à cadeira, sentindo pela primeira vez que aquilo não é uma ficção. ${ }^{32}$

Algo acontece durante as filmagens do documentário, algo de verdadeiramente profundo e de grande significado social e cultural. Algo que não obedece a um dizer unívoco: a câmara de filmar entra num espaço que, em princípio, seria de absoluta oclusão: 
o espaço doméstico, íntimo, secreto, deste modo desventrado, submetido ao olhar do terceiro excluído. Mas não é apenas este o acontecimento. Verdadeiramente determinante é, igualmente, a invisibilidade da câmara nesse espaço doméstico, íntimo, secreto. Esta invisibilidade não se verifica em todo o documentário, é certo, muito determinado pela auto-consciência dos diferentes intervenientes. Todavia, há momentos vários em que não se obedece a um script estabelecido ou previamente preparado. Nessas ocasiões pontuais, o grau de exposição devolve-nos uma sociedade ainda não imersa na cultura audiovisual, ou pelo menos que ainda não aprendeu as gramáticas dos media. Um desses momentos - do meu ponto de vista, sublinho, são vários, mas centro-me agora apenas num deles, fazendo dele exemplum de todos eles - acontece durante a conversa entre Leopoldo María, Michi e Felicidad nos jardins do colégio italiano que frequentaram na infância. Felicidad propusera um pequeno roteiro para estruturar a conversa. Os filhos aceitam. E, contudo, durante a efectiva filmagem da conversa, quando menos espero ouco a voz de Leopoldo María que começa a atacar-me. E agora já só me interessa defender-me. Não importa a câmara, sou eu com os meus velhos problemas, e tremem-me de raiva as mãos e as pálpebras. ${ }^{33}$

Eis aqui, pois, uma tensão que nem o documentário El desencanto nem o relato autobiográfico Espejo de sombras podem remover: a memória como imperativo que mobiliza o presente de Felicidad Blanc, que promove a sua construção como ego que diz ego; a memória como produção de amnésia, de esquecimento, pois ao ser cifrada como discurso - como dispositivo do pacto social -, perde o sujeito na sua singularidade. Na verdade, Espejo de sombras, do meu ponto de vista, é o enfrentamento ao efeito desrealizador do documentário; um enfrentamento que, no limite, produz mais desrealização; um enfrentamento que produz, enfim, mais desencanto. Como testemunho, ambos os textos plasmam a condição de um testemunho: testemunhar é ver, ver em terceira pessoa - a câmara representa esse terceiro olho do social que se imiscui no espaço íntimo da família Panero -, uma visão que instaura a possibilidade de ficção.

Romance familiar? História familiar? Sem dúvida, romance ou história como lendas, jogadas ora no registo épico, ora em declinação negra. É esta de resto a equação que instigaria a entrada de Leopoldo María Panero no filme. Na primeira metade do documentário, o poeta autor de Así se fundó Carnaby Street está ausente, a montagem final do filme introduz apenas uma breve sequência de um Leopoldo María Panero a vaguear por um cemitério, como fantasma, vampiro ou profanador de túmulos. O motivo vampírico activa, claramente, uma memória literária gótica - exacerbação romântica e malditismo teatralizado, cifra de uma temporalidade fora dos gonzos - mas também uma memória cinematográfica. Recorde-se, neste sentido, a inserção de sequências do Nosferatu, de Murnau, num filme de João César Monteiro muito próximo a El desencanto, documentário filmado em pleno ciclo revolucionário - refiro-me, concretamente, a Que Farei Eu Com Esta Espada?, de 1975. ${ }^{34}$

Ora, só a partir do meridiano do documentário irrompe a figura do poeta, fazendo-o, como manifesta diante da câmara, para contraditar a lenda épica da família Panero com a sua lenda negra. O momento que mais acima recordava de absoluta exposição de Felicidad Blanc à visão da câmara corresponde a esse gesto de contradição. Um double bind que se pode, ainda, re-descrever nos seguintes termos: o desencanto produz ficção, a 
produção de ficção produz mais desencanto. Tanto Felicidad Blanc como Leopoldo María Panero (enfim, também Juan Luis e Michi) querem corrigir a imagem que supostamente os representa. Uma pulsão que, diga-se, é muito romanesca, de uma vida subsumida pela arte, e a sua exautoração no plano inclinado da mentira. Por esses idos dos primeiros anos da década de 70, neste sentido, era traduzido para o espanhol o ensaio de Marthe Robert Roman des origines et origines du roman, onde precisamente se sobreleva o ímpeto não prioritariamente mimético do romance, antes decididamente transformador da realidade. ${ }^{35}$

A perda de especularidade do romance, de resto, é manifesta na pulsão genoclástica que percorre o breve corpus ficcional a que venho aludindo. A ruptura do objectivismo na ficção peninsular, a partir grosso modo da década de sessenta, soma diferentes episódios singulares. Uma Abelha na Chuva (cuja $1^{\mathrm{a}}$ ed. data de 1953, mas que viria a ter uma $4^{\mathrm{a}} \mathrm{e}$ definitiva versão em $1962^{36}$ ), de Carlos de Oliveira, inflecte de forma decisiva os imperativos da estética neo-realista. Romance sustentado por uma narração clivada entre o referencial e o auto-reflexivo, o universo social aí representado, uma comunidade rural dominada por valores morais pequeno-burgueses, contrasta com a pulsão modernista do processo enunciativo. ${ }^{37} \mathrm{O}$ narrador diabólico, isto é, o narrador auto-referencial de Uma Abelha na Chwva transfere para uma cena da escrita uma realidade que se representasse como exterior à representação, e que se movesse nessa exterioridade independendo de uma representação. O romance devém exercício filológico. ${ }^{38}$

De igual modo se perfila o acontecimento discursivo que é Tiempo de silencio (1962) de Luis Martín-Santos. Relevo desse romance, muito concretamente, a evanescência de um mundo que absolutamente se objectivasse, facto que na obra assume teor dramático na patologia da culpa de Pedro em relação à morte de Florita, corpo morto que acabará por significar a inconsequência do futuro casal Pedro/Dora. Cito: Tu não a mataste. Estava morta. Não estava morta. Mataste-a, sim. Porque razão dizes tu? - Eu $u^{39}$. Nem um objecto estável - isto é, nem uma realidade ontologicamente estável, de resto sub specie mortis -, nem um sujeito estável, definido antes como clivagem eu/tu no monologismo interior do foco narrativo. ${ }^{40}$

Também em Bolor (1968) de Augusto Abelaira, como sabemos, a referencialidade do género é, logo desde o início, truncada pela absolutização da escrita, pela omnipresença do romance como teatro da escrita. O universo representado é subsumindo por um enredo metaficcional, por uma escrita narcisista que coloca a referencialidade em perda. Eis o tropo da página em branco que determina a radical suspeição da ficção diarística proposta:

Olho para o papel branco (afinal um tudo-nada pardacento) sem a angústia de que falava Gauguin (ou era Van Gogh?) ao ver-se em frente da tela, mas com apreensão, apesar de tudo. Que vou eu escrever - eu, a quem nada neste mundo obriga a escrever? Eu, antecipadamente sabedor da inutilidade das linhas que neste momento ainda não redigi, dentro de alguns minutos (de alguns anos) finalmente redigidas? ${ }^{41}$

Visa-se, assim, o estranhamento do homo interior pequeno-burguês (sujeito escrevente), dado no romance pela falência matrimonial de Maria dos Remédios e Humberto, sintomática de um social amplamente alienado. 
Enfim, entre 1971 e 1975, Miguel Espinosa escreve um dos mais instigantes romances da segunda metade do século XX literário espanhol, La fea burguesía. Ainda seria revisto em 1980, e já só seria publicado na versão final em 1990. Edição póstuma, pois. La fea burguesía articula uma singularíssima poética romanesca, apostada na representação da burguesia, também referida como classe gozante. Classe, advirta-se, não obedece a um sentido estritamente materialista, nem o universo social representado se subsume a uma dialéctica de classes, antes à cristalização do seu cancelamento. O romance é constituído por duas partes. A primeira delas, sob o título de Classe média, é integrada por cinco histórias independentes. Cada uma delas centra-se num casal, sendo que cada um dos cinco casais nomeia as diferentes histórias: Castillejo e Cecilia, Clavero e Pilar, Krensler e Cayetana e Paracel e Purificación. A segunda parte do livro, por seu turno, tem por título Classe gozante. É composta por apenas um capítulo, subtitulado com os nomes de um outro casal, Camilo e Clotilde. Sublinho, enfim, um único aspecto formal deste romance, concretamente aquele que estrutura o pacto narrativo da segunda parte do livro. O narrador de Classe gozante é um narrador em primeira pessoa, o contador da história é precisamente a personagem Camilo. O pacto narrativo desta segunda metade de La fea burguesía implica que a voz ficcional que se dirige ao leitor seja um burguês exemplar. Esse leitor potencial, e este é um ponto importante, é ficcionado pelo próprio romance. A história é contada por Camilo, figura paradigmática da classe hedonista, a uma outra personagem, Godínez, indivíduo que se situa, de um ponto de vista social, nas margens do círculo propriamente burguês. Enquanto Camilo é um alto funcionário do aparelho burocrático do Estado - epítome pois da alta classe média que sustentou e foi legitimada pelo franquismo - Godínez pertence a um stratum social também referido como classe média, mas que não se manifesta absolutamente como classe gozante. $\mathrm{Na}$ verdade, a peculiaridade da personagem reside precisamente no facto de nunca poder vir a aceder a esse círculo social de eleição. Godínez é - e este termo é o termo usado no romance - um proletário. Ser proletário significa, dentro dos limites nocionais do romance, que Godínez é exposto à fealdade burguesa mas que nunca encarnará esse mal absoluto.

E, todavia, a condição de ouvinte e tentado pela sedutora língua de Camilo não esgota o estatuto ficcional de Godínez. Constatamo-lo apenas no último parágrafo do romance, que explicitamente situa Camilo e Godínez numa cena de tentação. Camilo é o tentador e Godínez o tentado. Camilo fala - narra, é o narrador - e Godínez escuta, isto é, é tentado pelo discurso da voz autoritária do primeiro. São estas as palavras finais do romance:

Um homem foi tentado, por outro homem, a inclinar-se diante do que não podia alcançar, dada a sua natureza, o que implica a mais alta tentação, pois conduz ao desespero. O tentado, contudo, resistiu à sedução mediante a acção de a escutar $e$ transcrever, retratando assim o tentador e afastando-o de si. $^{42}$

Notável este turn of the screw final do romance! Godínez não apenas ouve o relato de Camilo: Godínez é, também, responsável pela sua transcrição. Escrever as palavras da vida social alienada, da fealdade burguesa, significa simultaneamente ceder/resistir à alienação. 
O narrador diabólico de Uma Abelha na Chuva, o narrador clivado de Tiempo de silencio, a evanescência do foco narrativo em Bolor, e o complexo pacto narrativo de La fea burguesía, são figurae da lei formal do fenómeno estético que mais acima mediei pelas reflexões adornianas. Neste sentido, o compromisso - uma política do compromisso e o compromisso de uma resistência às ditaduras e à sociedade legitimada pelas demasiado longas ditaduras peninsulares - para estes escritores peninsulares, no cronótopo balizado pelas décadas de cinquenta e setenta, significou enfrentar as contradicções de uma estética desinteressada: todos perspectivam o estético (a poética dos seus romances) como alegoria de uma redenção social progressivamente privada de caução na história. Cada um destes escritores incorporou a consciência desesperada de que as Ditaduras pareceriam não ter fim. Como Beckett no ensaio de Adorno, esse desespero não sucumbe no silêncio, ainda que sejam contínguos: il faut continuer. Simultaneamente, empenhados como estavam na negação das sociedades salazarista/marcelista e franquista/tardofranquista, as suas escritas incorporaram um sentido de culpa, de cumplicidade em suma.

Processo à família [peninsular], pois, nas ficções de Felicidad Blanc e Leopoldo Panero, Maria dos Prazeres e Álvaro Silvestre, Dora e Pedro, Maria dos Remédios e Humberto, Castillejo e Cecilia, Clavero e Pilar, Krensler e Cayetana, Paracel e Purificación, Camilo e Clotilde... Um processo que, evidentemente, tem uma notória tradução política, ao ser a família fundamento ideológico das ditaduras peninsulares, ou não fossem etapas histórico-sociais legendadas pelo dictum Deus, Pátria, Família. Elenco de casais certamente incompleto - qual a soma dessas ficções matrimoniais? - mas que, sem obviar as diferenças das determinações contextuais dos romances em causa, nos convida a pensar a intimidade familiar como arca pectoris das sociedades corporativas peninsulares. O problema da babitação, jogado no inquilinato entre o estojo e o adereço, devolve-nos um complexo sintoma com que reequacionar as passagens das ditaduras para a democracias.

\section{Notas}

1 Idéia inicial de Michi Panero, o documentário acabaria por ser dirigido por Jaime Chávarri e produzido por Elías Querejeta.

2 BENJAMIN, Walter. Libro de los pasajes, ed. de Rolf Tiedman, trad. Luis Fernandes Castañeda, Isidro Herrera e Fernando Guerrero. Madrid: Akal, 2005, p. 242.

3 Idem, p. 239.

4 ABELAIRA, Augusto. A cidade das flores. 8 a ed. Lisboa: Edições O Jornal.

5 ADORNO, Theodor W. "Engagement” in Notas de Literatura. Rio de Janeiro: Biblioteca Tempo Universitário, 1973, p. 63.

6 ABELAIRA, Augusto. Quatro paredes nuas. Lisboa: Liv. Bertrand, 1972, p. 140.

7 Ibidem.

8 Idem, p. 142.

9 ABELAIRA, Augusto. Sem teto, entre ruinas. 2a ed. Lisboa: Sá da Costa, 1982 (1978), p. 17.

10 BLANC, Felicidad. Espejo de sombras. Barcelona: Argos Vergara, 1977, p. 245.

11 O final da autobiografia é o mar como imagem da morte, a ondulação, no seu vaia-e-vem, a espera que imobiliza: "Há algo na minha vida que é linear, inquebrantável, que nada pôde alterar. Nem as circunstâncias adversas, nem a guerra, nem o meu marido com uma personalidade tão absorvente, nem os meus filhos, puderam destruir o que fui, o que sou agora. O que procurei não o encontrei ou encontrei-o a meias, mas continuo a estar acompanhada pelos meus queridos fantasmas que são os mesmos de sempre. De vez em 
quando regresso a eles, limpo-lhes o pó e as teias-de-aranha e revivo de novo com eles os escassos momentos que foram" (idem, pp. 245-246).

12 RAGUÉ ARIAS, Maria José. Processo a la familia española. Barcelona: Gedisa, 1979, p. 22.

13 OLIVEIRA, Carlos de. Uma abelha na chuva. $25^{a}$ ed., Lisboa; Sá da Costa, 2001, p. 2. [1 ${ }^{\text {a }}$ ed.: 1953; $4^{\text {a }}$ ver.: 1962]. 14 Idem, p. 46.

15 OLIVEIRA, Carlos de. Obras de Carlos de Oliveira. s.l.: Editorial Caminho, 1992, p. 547.

16 Idem, p. 548.

17 ADORNO, Theodor W. Minima moralia. Reflexionem aus den deschädigten Leben. Frankfurt am Main: Suhrkamp Verlag, 1951, ed. cit. Minima moralia. Reflexiones desde la vida deñada, trad. Joaquim Chamorro Mielke. Madrid: Taurus, 1999. Traduzo este trecho da p. 27 do original para o português, fazendo-o muito embora pela tradução espanhola.

18 OLIVEIRA, Carlos de. Uma abelha..., p. 72.

19 ABELAIRA, Augusto. Bolor, $5^{a}$ ed. Lisboa: Edições O Jornal, 1986, p. 69.

20 Idem, p. 165.

21 LUHMAN, Niklas. Liebes als Passion. Frankfurt am Main. Surhkamp Verlag, 1982, p. 21; ed. cit.: O amor como paixão. Para a codificação da intimidade. Trad. F. Ribeiro. Lisboa: Difel, 1991.

22 Idem, p. 38.

23 Idem, p. 45.

24 Idem, p. 52.

25 Idem, p. 40.

26 Esta questão foi tratada por Vilma Arêas num notável ensaio sobre Augusto Abelaira, onde lemos: "Aos leitores de Abelaira não é estranha a idéia de que a individualidade em crise no mundo contemporâneo encontre seu contramolde nos muros desguarnecidos. Quatro Paredes Nuas, como sabemos, é o título de seu livro de contos, empenhado em tematizar essa questão. Segundo ele, a subjetividade não parece encontrar mais apoio material (quadros, memória, em suma, o 'tempo comprimido' da história individual) para interagir e conseqüentemente ex-sistir" "“Augusto Abelaira. A construção". In Jorge Fernandes da Silveira (org.) Escrever a Casa Portuguesa, Editora UFMG, 1999). Cf., também sobre Augusto Abelaira, Arêas, 1997.

27 VILARÓS, Teresa M. "La fea burguesía, de Miguel Espinosa: el pre - y el post - del desencanto español”. In AA.VV., Miguel Espinosa. Congresso. Murcia, Consejería de Cultura y Educación - Direción General de Cultura: Editora Regional de Murcia, 1992, p. 680.

28 Cf. idem. El mondo del desencanto. Una crítica cultural de la transición española (1973-1993). Madrid: Taurus, 1998.

29 BLANC, Felicidad. Op. cit., p. 230.

30 Idem, p. 243.

31 Idem, p. 244.

32 Idem, p. 243.

33 BLANC, 1977, p. 243. Eu sublinho.

34 A referência regressará, 20 anos depois, nas Recordações da Casa Amarela, na sequência final do filme, em que a personagem João de Deus emerge do subsolo da cidade de Lisboa, clara alusão ao vampiro de Murnau.

35 ROBERT, Marthe. Novelas de los origenes e y origenes de la novela. Madrid: Taurus, 1973, p. 31.

36 Cf. SANTOS, João Camilo dos. Carlos de Oliveira et le roman. Paris: Foundation Calouste Gulbenkian - Centre Culturel Portugais, 1987.

37 Esta fractura temporal - o tempo pré-histórico do mundo narrado, o tempo progressivo da narração - foi explicitado por DIOGO, Américo A. Lindeza. "Trabalhador ilegal”. In: Serra, Pedro (org). Uma abelha na cbuva. Uma revisão. Braga-Coimbra/Angelus Novus, 2003, pp. 149-187.

38 Cf. SERRA, Pedro. Romance \& Filologia. Almeida Garret, Eça de Queirós, Carlos de Oliveira. São Paulo: Nankin, 2004.

39 MARTÍN-SANTOS, Luis. Tiempo de silencio, 27ª ed., Barcelona: Deix Barral, 1987 [1962], p. 217. Eu traduzo. 40 Cf. KNICKERBOCKER, Dale F. “Tiempo de silencio and the narration of object in ALEC, vol. 19, issues 1-2,1994, p. 15.

41 ABELAIRA, Augusto. Bolor. Op. cit., p. 9.

42 ESPINOSA, Miguel. La Fea burguesía. Madrid: Alfaguara, 1990, p. 292. 